\title{
AFLP linkage map of the Japanese quail Coturnix japonica
}

\author{
Odile Roussot ${ }^{a *}$, Katia Feve $^{\mathrm{a}}$, Florence Plisson-Petit ${ }^{\mathrm{a}}$, \\ Frédérique Pitel ${ }^{\mathrm{a}}$, Jean-Michel FAure ${ }^{\mathrm{b}}$, Catherine BeAumont ${ }^{\mathrm{b}}$, \\ Alain VIGNAL ${ }^{\mathrm{a}}$ \\ ${ }^{a}$ Laboratoire de génétique cellulaire, Institut national de la recherche agronomique, \\ 31326 Castanet-Tolosan, France \\ b Station de recherches avicoles, Institut national de la recherche agronomique, \\ 37380 Nouzilly, France
}

(Received 26 December 2002; accepted 7 April 2003)

\begin{abstract}
The quail is a valuable farm and laboratory animal. Yet molecular information about this species remains scarce. We present here the first genetic linkage map of the Japanese quail. This comprehensive map is based solely on amplified fragment length polymorphism (AFLP) markers. These markers were developed and genotyped in an $\mathrm{F} 2$ progeny from a cross between two lines of quail differing in stress reactivity. A total of 432 polymorphic AFLP markers were detected with $24 \mathrm{TaqI} / E$ coRI primer combinations. On average, 18 markers were produced per primer combination. Two hundred and fifty eight of the polymorphic markers were assigned to 39 autosomal linkage groups plus the ZW sex chromosome linkage groups. The linkage groups range from 2 to 28 markers and from 0.0 to $195.5 \mathrm{cM}$. The AFLP map covers a total length of $1516 \mathrm{cM}$, with an average genetic distance between two consecutive markers of $7.6 \mathrm{cM}$. This AFLP map can be enriched with other marker types, especially mapped chicken genes that will enable to link the maps of both species and make use of the powerful comparative mapping approach. This AFLP map of the Japanese quail already provides an efficient tool for quantitative trait loci (QTL) mapping.
\end{abstract}

Japanese quail / AFLP / genetic map / linkage groups / chromosomes

\section{INTRODUCTION}

Japanese quail are appreciated for meat and eggs. It is also a valuable laboratory species because of its small body size, rapid generation interval and high prolificacy [24]. It has been used in selection experiments (e.g. [6,34]), and as a model for a variety of studies in embryonic development, genetics,

\footnotetext{
* Correspondence and reprints
}

E-mail: roussot@toulouse.inra.fr 
perception and behaviour and their neurological basis, reproduction, nutrition, production and pathology.

Japanese quail (Coturnix japonica), as the chicken (Gallus gallus), belongs to the order Galliformes and the family Phasianidae. Both species have a similar genome length $\left(1.2 \times 10^{9} \mathrm{bp}\right)$ and a karyotype of $2 n=78$ chromosomes, composed of morphologically distinguishable macrochromosomes (1-8 and the ZW sex chromosomes) and individually indistinguishable microchromosomes. Comparative cytogenetic studies, based on banding patterns or chromosome painting using FISH, have revealed a highly conserved chromosome homology: the few chromosome rearrangements observed were essentially pericentric inversions in chromosomes $1,2,4$ and $8[35,37,40]$. Today, the consensus linkage map of the chicken genome has almost 2000 loci [8] whereas only three linkage groups involving protein and plumage colour loci have been reported for the quail $[12,13,25,36]$.

In linkage studies, microsatellite markers are currently used because they are highly polymorphic and codominantly inherited. However, they occur at about a 5-7-fold lower frequency in avian genomes than in mammals [30] and are thought to be biased in their distribution [30,38]. In addition, cross-species microsatellite amplification in birds is successful only at a low rate. On average, with chicken designed primers, $10-15 \%$ of the amplified markers in the Japanese quail are found to correspond to the orthologous loci of the chicken [11, 28]. This does not guarantee these microsatellites to be polymorphic in the populations studied. As a consequence, a sufficient set of markers for genome mapping cannot be recovered by this method. Microsatellites have only very recently been specifically developed in the Japanese quail $[15,16$, 21].

To develop a genetic map of the Japanese quail, we chose the amplified fragment length polymorphism (AFLP) technique [45]. In contrast to microsatellite markers, the AFLP technology screens a high number of loci and generates numerous markers, simply using a generic set of primers, without requiring prior knowledge of sequence data. It has been extensively applied to microorganisms and plants, but rarely to animals $[1,9,42]$. These applications include many genetic diversity studies as well as the construction of linkage maps or quantitative trait loci (QTL) mapping. In particular, the AFLP technique was demonstrated to be useful in the chicken to add new markers on the EL (East Lansing) reference map [17] and on the Wageningen linkage map [10]. Its suitability for other avian species has also been suggested. As in these studies, we adopted the enzyme combination TaqI/EcoRI and trinucleotide primer extensions to produce AFLP markers in the Japanese quail. We present here the first linkage map for this species, based solely on AFLP markers. 


\section{MATERIALS AND METHODS}

\subsection{Mapping population}

An F2 cross between two Japanese quail lines divergently selected for short or long duration of tonic immobility [5,23], a fear-related freezing behaviour, was performed. Six half-sib families originating from 6 F1 sires and 12 F1 dams were used as the mapping population. The average number of chicks per F1 female was $58 \pm 6$. For one full-sib family, all the chicks were analysed. For the others, an average of $23 \pm 3$ chicks were genotyped. These F2 birds were selected on the basis of their trait value, since this population also served for a QTL study. A total of 348 animals was genotyped: 20 F0, 18 F1, 310 F2 animals.

\subsection{DNA isolation}

Genomic DNA was extracted from blood samples with a rapid high-salt protocol scaled to a 96-well microplate format. In each well, a $2 \mu \mathrm{L}$ blood sample was incubated $10 \mathrm{~min}$ at room temperature with $10 \mu \mathrm{L}$ cell lysis buffer (20 mM EDTA, $60 \mathrm{mM} \mathrm{NaCl}, 0.2 \%$ saponine Sigma). Twenty $\mu \mathrm{L}$ of wash buffer $(10 \mathrm{mM}$ EDTA, $75 \mathrm{mM} \mathrm{NaCl})$ was added and, after centrifugation (1300 $\mathrm{g}$, $15 \mathrm{~min}$, Megafuge $1.0 \mathrm{R}$, Heraeus Sepatech), the supernatant was discarded. The nuclei lysis was performed overnight at $37^{\circ} \mathrm{C}$ with $80 \mu \mathrm{L}$ of an SDS-Proteinase K solution (10 mM EDTA, $10 \mathrm{mM} \mathrm{NaCl}, 10 \mathrm{mM}$ Tris $\mathrm{HCl}$, $0.5 \%$ SDS, $100 \mu \mathrm{g} \cdot \mathrm{mL}^{-1}$ Proteinase K Quantum Appligene). To achieve protein precipitation, $30 \mu \mathrm{L}$ of a saturated $(6 \mathrm{M}) \mathrm{NaCl}$ solution was added and the sample was vigorously mixed and centrifuged $(1300 \mathrm{~g}, 30 \mathrm{~min})$. The supernatant was transferred to a fresh $0.65 \mathrm{~mL}$ microplate well (Deep Well Plate, $0.65 \mathrm{~mL}$, ABGene) and the DNA was precipitated with $250 \mu \mathrm{L}$ absolute ethanol. After centrifugation $(1300 \mathrm{~g}, 30 \mathrm{~min})$, the ethanol was discarded. The DNA samples were air dried and redissolved in $200 \mu \mathrm{L}$ Tris-EDTA buffer (10 mM Tris $\mathrm{HCl}, 0.1 \mathrm{mM}$ EDTA pH 7.5). The DNA quantity and quality were assessed by agarose gel electrophoresis.

\subsection{AFLP analysis}

AFLP markers were generated following the conditions summarised in Table I. Preamplification primers were extended by one base, an adenine, at their $3^{\prime}$ end. Amplification primers were extended by 2 additional selection nucleotides. Primer combinations, of which 27 were analysed on the mapping population, had been previously selected according to line-specific DNA pool patterns. 
Table I. AFLP protocol.

\begin{tabular}{|c|c|c|c|c|}
\hline Step & Reaction mix & Final volume & \multicolumn{2}{|l|}{ Conditions } \\
\hline Restriction & 400 ng genomic DNA & & \multirow{2}{*}{\multicolumn{2}{|c|}{$3 \mathrm{~h}, 65^{\circ} \mathrm{C}$}} \\
\hline & $10 \mathrm{U} \mathrm{TaqI}(\mathrm{Neb})$ & $40 \mu \mathrm{L} \mathrm{RL}^{1}$ buffer & & \\
\hline & $\begin{array}{l}+ \\
10 \mathrm{U} E c o \mathrm{RI}(\mathrm{Neb})\end{array}$ & $50 \mu \mathrm{L}$ RL buffer & \multicolumn{2}{|c|}{ overnight, $37^{\circ} \mathrm{C}$} \\
\hline \multicolumn{5}{|c|}{$10 \mu \mathrm{L}$ of the digestion mix checked on $0.8 \%$ agarose gel } \\
\hline \multicolumn{5}{|c|}{ remaining $40 \mu \mathrm{L}$ used in the ligation step } \\
\hline Ligation & $\begin{array}{l}+ \\
50 \text { pmol TaqI adapter } \\
2 \\
5 \text { pmol EcoRI adapter }{ }^{3} \\
1 \text { U T4 DNA ligase } \\
\text { (Q-Biogene) } \\
1.2 \text { mM ATP }\end{array}$ & $50 \mu \mathrm{L}$ RL buffer & \multicolumn{2}{|c|}{ overnight, $37^{\circ} \mathrm{C}$} \\
\hline \multicolumn{5}{|c|}{ dilution 2-, 5- or 10-fold according to restriction smear intensity } \\
\hline $\begin{array}{l}\text { Pre- } \\
\text { amplification }\end{array}$ & $\begin{array}{l}5 \mu \mathrm{L} \text { diluted template DNA } \\
0.2 \mu \mathrm{M} \mathrm{TaqI}+\text { A primer } \\
0.2 \mu \mathrm{M} \mathrm{EcoRI}+\text { A primer }^{5} \\
0.2 \mathrm{mM} \mathrm{dNTP} \\
2 \mathrm{mM} \mathrm{MgCl} 2 \\
0.5 \mathrm{U} \mathrm{Taq} \text { polymerase } \\
\text { (Gibco BRL) }\end{array}$ & $\begin{array}{l}20 \mu \mathrm{L} \text { PCR buffer } \\
+ \\
5 \mu \mathrm{L} \text { coloured } \\
\text { loading buffer }\end{array}$ & $\begin{array}{l}\begin{array}{l}30 \mathrm{~s}, 94^{\circ} \mathrm{C} \\
30 \mathrm{~s}, 59^{\circ} \mathrm{C} \\
60 \mathrm{~s}, 72^{\circ} \mathrm{C}\end{array} \\
9 \mathrm{~min}, 72^{\circ} \mathrm{C} \\
\begin{array}{l}\text { GeneAmp PC } \\
\text { system } 9700 \\
\text { (Perkin-Elm }\end{array}\end{array}$ & $\begin{array}{l}\text { CR } \\
\text { thermocycler } \\
\text { r) }\end{array}$ \\
\hline \multicolumn{5}{|c|}{$10 \mu \mathrm{L}$ preamplified DNA checked on $0.8 \%$ agarose gel } \\
\hline Amplification & $\begin{array}{l}2 \mu \mathrm{L} \text { diluted preamplified DNA } \\
0.2 \mu \mathrm{M} 3 \mathrm{nt} \text { TaqI-primer } \\
0.2 \mu \mathrm{M} 3 \mathrm{nt} \text { EcoRI-primer }{ }^{6} \\
0.2 \mathrm{mM} \mathrm{dNTP} \\
2 \mathrm{mM} \mathrm{MgCl} \\
0.2 \mathrm{U} \mathrm{Taq} \text { polymerase } \\
\text { (Gibco BRL) }\end{array}$ & $10 \mu \mathrm{L}$ PCR buffer & 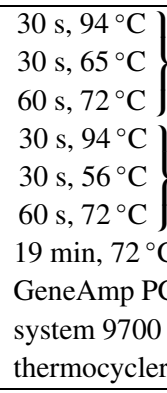 & $\begin{array}{l}12 \text { cycles } \\
-1^{\circ} \mathrm{C} / \text { cycle } \\
30 \text { cycles } \\
\text { R } \\
\text { or } 9600 \\
\text { (PE) }\end{array}$ \\
\hline Separation & $\begin{array}{l}2 \mu \mathrm{L} \text { equally mixed } \\
\text { 6-FAM, HEX and NED } \\
\text { labelled PCR products } \\
8 \mu \mathrm{L} \text { formamide Hi-Di } \\
\left(\mathrm{ABI}{ }^{\circledR}, \mathrm{PE}\right) \\
0.12 \mu \mathrm{L} \text { ROX } 500 \text { size standard }\end{array}$ & & $\begin{array}{l}5 \text { min denatu } \\
94^{\circ} \mathrm{C}\end{array}$ & ation, \\
\hline injection and $\mathrm{r}$ & resolution on capillary sequencer & $\mathrm{ABI}^{\circledR} 3700 \mathrm{DNA} \mathrm{An}$ & yzer, PE) & \\
\hline $\begin{array}{l}{ }^{1} \mathrm{RL} \text { (restricti } \\
{ }^{2} \text { Taq I adapter } \\
{ }^{3} \text { EcoRI adapt } \\
{ }^{4} \text { TaqI primer: } \\
{ }^{5} \text { EcoRI prime }\end{array}$ & $\begin{array}{l}\text { ion ligation) buffer: } 10 \% \text { OPA (Ph } \\
\text { r: 5'-GACGATGAGTCCTGAC-3 } \\
\text { ter: } 5^{\prime} \text {-CTCGTAGACTGCGTTAC } \\
\text { : 5'-GATGAGTCCTGACCGA-3' } \\
\text { er: 5'-CTGCGTTACCAATTC-3'; }\end{array}$ & $\begin{array}{l}\text { armacia Biotech) } 5 \mathrm{~m} \\
\text { 3'-TACTCAGGAC } \\
\text { C-3' 3'-CTGACGCA }\end{array}$ & $\begin{array}{l}\text { A dTT, } 50 \mu \mathrm{g} \cdot \\
\text { IGC-5'; } \\
\text { ITGGTTAA-5 }\end{array}$ & $\mathrm{mL}^{-1} \mathrm{BSA}$ \\
\hline
\end{tabular}


Resulting electrophoregrams were checked with Genescan ${ }^{\circledR} 3.5$ and analysed using Genotyper ${ }^{\circledR} 3.6\left(\mathrm{ABI}^{\circledR}, \mathrm{PE}\right)$. Markers between 50 and 500 bp were identified visually from F0 and F1 animal patterns. Marker peaks were then detected automatically and checked manually in all the lanes. AFLP markers were named after the $T a q$ I primer extension followed by the EcoRI primer extension and the fragment size in bp. They were scored dominantly: band absence (recessive homozygous) was coded 11, band presence (heterozygous or dominant homozygous) 20. Missing data were coded as 00.

\subsection{Map construction}

Prior to linkage analysis, a $\chi^{2}$ test $(P=0.05)$ was performed for each marker in each of the 12 full-sib families in order to check Mendelian inheritance. Data displaying an unexpected segregation ratio were excluded.

Linkage analyses were conducted with CRI-MAP 2.4 [7]. First, the twopoint option of CRI-MAP was used to calculate pairwise LOD scores and to identify linkage groups at decreasing values of the LOD threshold, from 10 to 4 . Second, the linear order of markers within each linkage group was determined using the build and flips options of CRI-MAP. To begin, build was run several times with LOD values of 3 and 2 , to find a well supported order for a subset of markers. As many additional markers as possible were then inserted in their most probable position relative to the previously ordered markers. The most likely order was finally checked with fips. Map distances are given by CRI-MAP according to the Kosambi function.

One linkage group was suspected to correspond to the sex chromosomes, ZW. This was confirmed creating a biallelic sex marker, designed to follow the inheritance of the $\mathrm{W}$ chromosome, and running the twopoint option of CRI-MAP. Raw data were reconsidered in order to identify $\mathrm{Z}$ or $\mathrm{W}$ markers, attested by a sex-specific segregation ratio, and to build a map for these two chromosomes. Markers outside of this linkage group were also tested for linkage to the biallelic sex marker.

\section{RESULTS}

\subsection{AFLP markers}

Of the selected primer combinations, twenty-four were analysed and 3 (ACGAAA, ACGAAC, ACGAGC) were not further studied because they produced patterns of poor quality. The $24 \mathrm{Taq} / \mathrm{EcoRI}$ primer combinations analysed generated more than 4000 bands, of which 432 were considered as polymorphic markers and typed in the population (Tab. II). On average, each primer combination yielded 18 polymorphic markers. 
Table II. Primer combinations used - AFLP markers produced and mapped.

\begin{tabular}{|c|c|c|c|}
\hline $\begin{array}{l}\text { Primer } \\
\text { combination }\end{array}$ & $\begin{array}{c}\text { Number of } \\
\text { peaks }\end{array}$ & $\begin{array}{c}\text { Number of polymorphic } \\
\text { markers }\end{array}$ & $\begin{array}{c}\text { Number of mapped } \\
\text { markers }\end{array}$ \\
\hline$A A C A A A$ & 298 & 56 & 25 \\
\hline АACATA & 232 & 22 & 10 \\
\hline$A A C A G C$ & 275 & 29 & 18 \\
\hline$A G A A A A$ & 83 & 19 & 13 \\
\hline AGAATA & 91 & 14 & 4 \\
\hline$A G A A G C$ & 118 & 28 & 17 \\
\hline$A A C A A T$ & 192 & 17 & 12 \\
\hline$A A C A C C$ & 125 & 15 & 10 \\
\hline$A A C A A G$ & 120 & 18 & 12 \\
\hline$A G T A A A$ & 222 & 17 & 11 \\
\hline AGTACC & 146 & 25 & 15 \\
\hline$A G T A G G$ & 171 & 20 & 10 \\
\hline$A G C A A A$ & 118 & 19 & 14 \\
\hline AGCATA & 123 & 11 & 6 \\
\hline$A G C A G G$ & 146 & 24 & 13 \\
\hline ACGATC & 283 & 12 & 8 \\
\hline$A C G A C C$ & 134 & 5 & 1 \\
\hline$A C G A A G$ & 194 & 4 & 2 \\
\hline ACCATG & 121 & 4 & 4 \\
\hline$A C C A C G$ & 131 & 4 & 3 \\
\hline$A C C A G G$ & 189 & 7 & 4 \\
\hline$A G A A T G$ & 149 & 28 & 22 \\
\hline$A G A A C C$ & 245 & 23 & 17 \\
\hline \multirow[t]{2}{*}{$A G A A C T$} & 232 & 11 & 7 \\
\hline & 4138 & 432 & 258 \\
\hline
\end{tabular}

The data comprised $1.4 \%$ of missing genotypes and $0.5 \%$ of inconsistencies between parents and progeny alleles. Considering the presence $v s$. absence of a band in the F0 birds, $27.1 \%$ of the polymorphic markers were found to be line specific (the marker peak was present in the F0 birds of one of the two lines only, but not necessarily in all the F0 birds of this line) and another 12.0\% were present in both lines with significantly different frequencies $(>0.5)$. The markers were rarely informative in all the families. On average, per full-sib family, $60.6 \pm 4.8 \%$ of the markers were informative and $13.6 \pm 5.9 \%$ showed a deviation from the expected ratios at the $P=0.05$ level. Following the $\chi^{2}$ test on Mendelian inheritance, $23.8 \%$ of the data were excluded. Only six markers were completely excluded from linkage analysis, being either non informative or segregating in a non-Mendelian fashion. 


\subsection{AFLP linkage map}

To define linkage groups, decreasing LOD threshold values were used. At a LOD of 5, some of the major linkage groups were merged due to a few linkages that were likely spurious. Also, the number of additional markers that were integrated at this LOD value did not justify lowering the threshold. Therefore a LOD cut-off value of 6 was preferred.

The AFLP linkage map comprises 258 markers (59.7\%) distributed over 39 autosomal linkage groups plus the ZW linkage groups (Fig. 1) while 174 markers (40.3\%) remain unlinked at the LOD threshold used. Linkage groups vary from 2 to 28 markers. There are 11 major linkage groups of 8-28 markers and 30 minor groups of 6 markers or less.

Of the 23 markers of the gonosome linkage group, eight W-specific markers were found. One marker presents a normal autosomal segregation and is therefore thought to belong to the pseudo-autosomal region. The other 14 markers, presenting male-specific inheritance, were considered as Z-specific markers. A schematic representation is given for the $\mathrm{W}$ chromosome since no recombination occurs along its specific part and hence, no order can be inferred.

The AFLP linkage map of the Japanese quail covers a total length of $1516 \mathrm{cM}$. Linkage groups range from 0.0 to $195.5 \mathrm{cM}$. The spacing between two consecutive markers ranges from 0.0 to $37 \mathrm{cM}$, with an average of $7.6 \pm 6.2 \mathrm{cM}$. There are 17 pairs of markers in complete linkage in the autosomal linkage groups and 7 markers in the $\mathrm{W}$ linkage group. For the latter, such a segregation pattern was expected and the markers are likely to correspond to different loci. For the former, two markers can result from the amplification of the same locus. The number of mapped loci can thus be estimated to be at least $258-17=241$. On the whole, the markers are close together and regularly distributed. The markers generated by the same primer combination are shared out among different linkage groups, except for the AACATA combination that produced many of the ZW markers.

\section{DISCUSSION}

Thanks to its multilocus nature and because potentially all possible primer combinations can be tested, the AFLP technique enables the production of a large number of polymorphic markers. The biological material used also contributes to the level of revealed polymorphism and indeed, the quail is generally considered as a highly polymorphic species. The proportions of line-specific markers $(27.1 \%)$ and of shared markers with significant frequency differences (12.0\%) help assess the level of between line polymorphism. The AFLP patterns generated from Japanese quail DNA were complex. An average of 18 polymorphic markers per primer combination was obtained, which is 
1

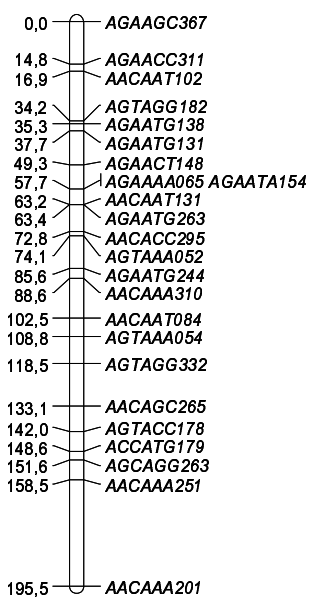

5

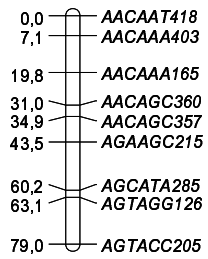

7

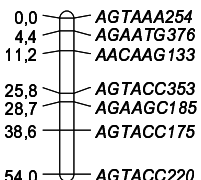

2

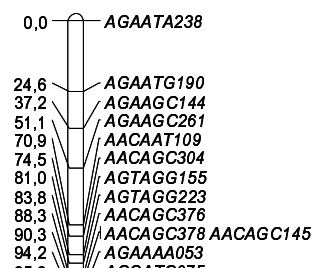

( AGAAAAO53

97, WGAAAA107

97.2 AGCAGG140

103,5 AGAACC 300

05,4 AGACC180

10,1 AACAAG186

AGAACTO51

132, $1-A G C A A A 070$

135,8 AACAAA334

46, AGAATG124

14.2 AGCAAAO97

A 148,6 AGAATG127

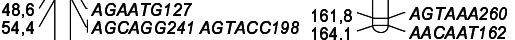

$172,1-$ AGCAGG256

172,1 AGCAGG256

6

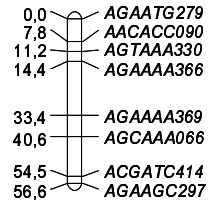

8

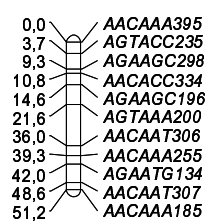

3

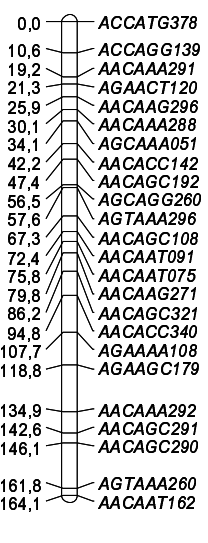

$\mathbf{Z}$

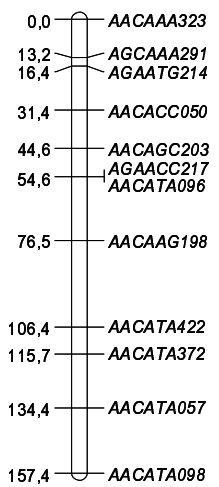

4

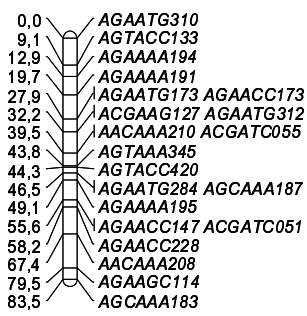

Figure 1. AFLP genetic linkage map of the Japanese quail. The map is composed of 39 autosomal linkage groups plus the ZW sex chromosome linkage groups. Markers are indicated on the right, their position in centimorgans on the left. Within each group, markers are presented in their most likely order. A theoretical representation of the $\mathrm{W}$ chromosome linkage group is given since the distance between the pseudo-autosomal and the $\mathrm{W}$ specific markers cannot be properly estimated (dashed line). Markers that could not be inserted ( 3 in the $\mathrm{Z}$ chromosome linkage group, 2 in group 7, 3 in group 8,1 in group 9 and 1 in group 26) and unlinked markers are not shown in the figure. The map was drawn with MapChart $2.0^{\odot}$ software [44].

(continued on the next page) 


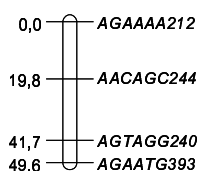

10

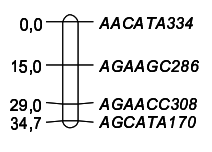

11

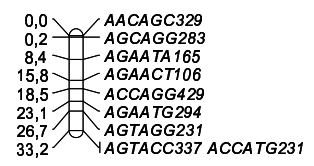

12

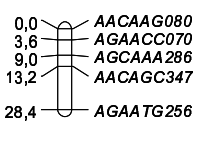

17

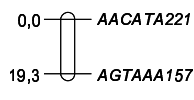

21

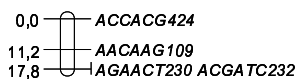

13

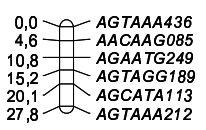

18

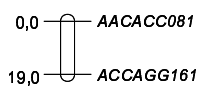

22

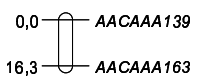

27

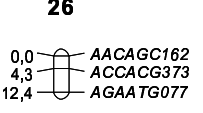

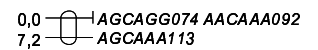

38
31

32

0,0- $A C G A T C 133$

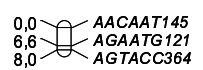

36

37

$0,0 \bigcirc$ AACAAA262

\section{4}

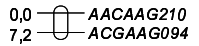

35

$0,0-A A C A C C 421$
0,0- $A$ ACAAA051 $6,4-$ AGAAAA149

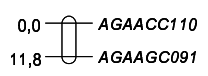

39

$0,0-\bigcirc$ IAACAAA159 AGAATG269

$0,0-\bigcirc$ AGAACC231 AGAATA171

Figure 1. Continued.

twice as much as in the chicken (10.5 [17], 8.5 [10]), with the same enzyme combination and the same primer extension length (3 nt).

Technical and biological reasons can explain segregation distortion $[20,41]$. Inconsistencies in the genotype proportions can be due to genotyping errors, to fragments of the same size scored as a single marker whereas they are derived from distinct loci or to a selective advantage as suggested in plants [3, 27] and fish [48]. Non-Mendelian segregating markers occur at various rates: for instance $15 \%$ in peach rootstocks [20], 27.4\% in rice [4], 56\% in the silkworm [41], and 64\% in Brassica oleracea [43]. On average, in each family, only $13.6 \pm 5.9 \%$ of the AFLP markers developed in the Japanese quail were distorted. As the markers were not informative in all the families, the average 
proportion of informative and Mendelian segregating markers, $47.0 \pm 3.9 \%$, better represents the usefulness of the data. This figure is in accordance with the studies mentioned earlier.

Linkage groups were identified with a high threshold, related to the number of markers to be tested. Increasing the twopoint threshold favours closely linked markers and the closer markers are, the more complicated it becomes to resolve their order. Ordering the markers can present other difficulties. The information content of AFLP markers is lower than that of other marker types because of their biallelic dominant nature. Furthermore, informativeness in our design is shared out between several families. Finally, our map contains only AFLP markers. In many studies, markers such as RFLP (restriction fragment length polymorphism), CAPS (cleaved amplified polymorphic sequence), microsatellites or genes are used together with AFLP markers. They can provide clues about the chromosome assignment of linkage groups or links to existing maps [2,31], but they can also give a framework to which AFLP markers are added [4]. Here, the markers are presented in their most likely order. Alternative orders can exist, whose likelihoods differ from that of the proposed order by a LOD value of less than 2 or 3 . Additional markers will help improve the map robustness.

The map is relatively dense with an average interval size between adjacent markers of $7.6 \mathrm{cM}$. Although some linkage groups present higher marker densities, no tight clustering of the markers was observed, as opposed to other species [29,32] where it seems to be a consequence of the enzyme combinations used. Within primer combinations, no clustering was observed either, except for markers of the AACATA combination that map on the $\mathrm{Z}$ and $\mathrm{W}$ chromosomes. Herbergs et al. [10] also found a high number of $Z$ linked markers working in the chicken with the same enzyme combination. The number of markers of similar size on the $\mathrm{W}$ chromosome is also surprising. In both cases, the presence of repetitive sequences on these chromosomes, as described in the chicken $[26,35,39]$, can be suspected to account for this observation.

A large number of chromosomes makes it difficult to build an exhaustive map, especially in the case of avian species and their microchromosomes. So, even if the number of linkage groups is actually similar to that of chromosomes, some of them might likely correspond to different parts of the same chromosome, while some microchromosomes are not represented. However, AFLP markers can be expected to provide a better coverage of microchromosomes than microsatellites. Indeed, as a result of the GC-rich and gene-dense nature of microchromosomes $[22,38]$ together with the type of polymorphism revealed by each technique, microsatellites are underrepresented on these chromosomes [30], whereas the AFLP technique, using TaqI or other enzymes, such as MspI or HinP1I [17] with GC-rich recognition sites, could better target these zones. 
Our map spans a total length of $1516 \mathrm{cM}$. Considering that $60 \%$ of the markers are mapped and ignoring the two ends of each linkage group, an estimation of the genetic length of the Japanese quail genome would be $\sim 2530 \mathrm{cM}$. This is in agreement with recent cytological maps of lampbrush chromosomes in the Japanese quail [33]. This is also comparable to the first estimates of the chicken genome genetic length [19]. However, a greater genetic length can be expected for the quail since the more recent consensus linkage map in the chicken spans $\sim 3800 \mathrm{cM}[8]$.

In order to allocate linkage groups to chromosomes and to have physical data to assess genome coverage, an efficient strategy is to map a set of genes of known location in the chicken on the Japanese quail AFLP map. This will allow to take advantage of the power of comparative genetic and cytogenetic approaches between these species. AFLP markers have been shown to map to the same loci in different populations, for instance in barley [47], oat [14], maize [46], chicken [18] or trout [32]. They can be expected to behave in the same manner in the quail and therefore some of the markers developed in this study might be useful in other quail lines or populations. On the contrary, using markers of common size and common primer combination origin in quail and chicken for comparative mapping purposes would be hazardous.

This Japanese quail AFLP map will be enriched with genes. Recently developed microsatellites in this species are also available [15,16,21]. This map already provides a basis for identifying and studying regions, and eventually genes, involved in the genetic control of complex traits (QTL).

\section{ACKNOWLEDGEMENTS}

This work was supported in part by Aventis Animal Nutrition and the Génopôle Toulouse Midi-Pyrénées. AFLP is a trademark filed by Keygene NV, The Netherlands.

\section{REFERENCES}

[1] Agrama H.A., Houssin S.F., Tarek M.A., Cloning of AFLP markers linked to resistance to Peronosclerospora sorghi in maize, Mol. Genet. Genomics 267 (2002) 814-819.

[2] Alonso-Blanco C., Peeters A.J., Koornneef M., Lister C., Dean C., Van den Bosch N., Pot J., Kuiper M.T., Development of an AFLP based linkage map of Ler, Col and Cvi Arabidopsis thaliana ecotypes and construction of a Ler/Cvi recombinant inbred line population, Plant J. 14 (1998) 259-271.

[3] Cervera M.T., Gusmao J., Steenackers M., Peleman J., Storme V., Van den Broeck A., Van Montagu M., Boerjan W., Identification of AFLP molecular markers for resistance against Melampsora larici-populina in Populus, Theor. Appl. Genet. 93 (1996) 733-737. 
[4] Cho Y.G., Mc Couch S.R., Kuiper M., Kang M.R., Pot J., Groenen J.T.M., Eun M.Y., Integrated maps of AFLP, SSLP and RFLP markers using a recombinant inbred population of rice (Oryza sativa L.), Theor. Appl. Genet. 97 (1998) 370380.

[5] Faure J.M., Mills A.D., Improving the adaptability of animals by selection, in: T. Grandin (Ed.), Genetics and the Behavior of Domestic Animals, Academic Press, 1998, pp. 235-264.

[6] Gerken M., Petersen J., Bidirectional selection for dustbathing activity in Japanese quail (Coturnix coturnix japonica), Brit. Poultry Sci. 28 (1987) 23-37.

[7] Green P., Falls K., Crooks S., Documentation for CRI-MAP, version 2.4, Washington University School of Medicine, St Louis, 1990.

[8] Groenen M.A., Cheng H.H., Bumstead N., Benkel B.F., Briles W.E., Burke T., Burt D.W., Crittenden L.B., Dodgson J., Hillel J., Lamont S., de Leon A.P., Soller M., Takahashi H., Vignal A., A consensus linkage map of the chicken genome, Genome Res. 10 (2000) 137-147.

[9] Guerra M.M., Bernardo F., McLauchlin J., Amplified fragment length polymorphism (AFLP) analysis of Listeria monocytogenes, Syst. Appl. Microbiol. 25 (2002) 456-461.

[10] Herbergs J., Siwek M., Crooijmans R.P., Van der Poel J.J., Groenen M.A., Multicolour fluorescent detection and mapping of AFLP markers in chicken (Gallus domesticus), Anim. Genet. 30 (1999) 274-285.

[11] Inoue-Murayama M., Kayang B.B., Kimura K., Ide H., Nomura A., Takahashi H., Nagamine Y., Takeda T., Hanada H., Tatsuda K., Tsudzuki M., Matsuda Y., Mizutani M., Murayama Y., Ito S., Chicken microsatellite primers are not efficient markers for Japanese quail, Anim. Genet. 32 (2001) 7-11.

[12] Ito S., Kimura M., Isogai I., A sex difference in recombination values between extended brown and phosphoglucose isomerase loci in Japanese quail, Jpn J. Zootech. Sci. 59 (1988) 801-805.

[13] Ito S., Kimura M., Isogai I., Linkage between panda plumage and albumin loci in Japanese quail, Jpn J. Zootech. Sci. 59 (1988) 822-824.

[14] Jin H., Domier L.L., Kolb F.L., Brown C.M., Identification of quantitative trait loci for tolerance to barley yellow dwarf virus in oat, Phytopathology 88 (1998) 410-415.

[15] Kayang B.B., Inoue-Murayama M., Nomura A., Kimura K., Takahashi H., Mizutani M., Ito S., Fifty microsatellite markers for Japanese quail, J. Hered. 91 (2000) 502-505.

[16] Kayang B.B., Inoue-Murayama M., Hoshi T., Matsuo K., Takahashi H., Minezawa M., Mizutani M., Ito S., Microsatellite loci in Japanese quail and cross-species amplification in chicken and guinea fowl, Genet. Sel. Evol. 34 (2002) 233-253.

[17] Knorr C., Cheng H.H., Dodgson J.B., Application of AFLP markers to genome mapping in poultry, Anim. Genet. 30 (1999) 28-35.

[18] Knorr C., Cheng H.H., Dodgson J.B., DNA cloning and sequence analysis of chicken AFLP, Anim. Genet. 32 (2001) 156-159.

[19] Levin I., Santangelo L., Cheng H., Crittenden L.B., Dodgson J.B., An autosomal genetic linkage map of the chicken, J. Hered. 85 (1994) 79-85. 
[20] Lu Z.X., Sosinski B., Reighard G.L., Baird W.V., Abbott A.G., Construction of a genetic linkage map and identification of AFLP markers for resistance to root-knot nematodes in peach rootstocks, Genome 41 (1998) 199-207.

[21] Mannen H., Murata K., Mizutani M., Tsuji S., Development of microsatellite markers from a heart cDNA library in Japanese quail, in: ISAG (Ed.), XXVIII International Conference on Animal Genetics, Göttingen, Proceedings 2002, Blackwell Publishing, Part5, D082.

[22] McQueen H.A., Siriaco G., Bird A.P., Chicken microchromosomes are hyperacetylated, early replicating, and gene rich, Genome Res. 8 (1998) 621-630.

[23] Mills A.D., Faure J.M., Divergent selection for duration of tonic immobility and social reinstatement behavior in Japanese quail (Coturnix coturnix japonica) chicks, J. Comp. Psychol. 105 (1991) 25-38.

[24] Mills A.D., Crawford L.L., Domjan M., Faure J.M., The behavior of the Japanese or domestic quail Coturnix japonica, Neurosci. Biobehav. Rev. 21 (1997) 261281.

[25] Minvielle F., Ito S., Inoue-Murayama M., Mizutani M., Wakasugi N., Genetic analyses of plumage color mutations on the $\mathrm{Z}$ chromosome of Japanese quail, J. Hered. 91 (2000) 499-501.

[26] Mizuno S., Mac Gregor H., The ZW lampbrush chromosome of birds: a unique opportunity to look at the molecular cytogenetics of sex chromosomes, Cytogenet. Cell Genet. 80 (1998) 149-157.

[27] Nandi S., Subudhi P.K., Senadhira D., Manigbas N.L., Sen-Mandi S., Huang N., Mapping QTLs for submergence tolerance in rice by AFLP analysis and selective genotyping, Mol. Gen. Genet. 255 (1997) 1-8.

[28] Pang S.W., Ritland C., Carlson J.E., Cheng K.M., Japanese quail microsatellite loci amplified with chicken-specific primers, Anim. Genet. 30 (1999) 195-199.

[29] Powell W., Thomas W.T.B., Baird E., Lawrence P., Booth A., Harrower B., McNicol J.W., Waugh R., Analysis of quantitative traits in barley by the use of amplified fragment length polymorphisms, Heredity 79 (1997) 48-59.

[30] Primmer C.R., Raudsepp T., Chowdhary B.P., Moller A.P., Ellegren H., Low frequency of microsatellites in the avian genome, Genome Res. 7 (1997) 471482.

[31] Quarrie S.A., Laurie D.A., Zhu J., Lebreton C., Semikhodskii A., Steed A., Witsenboer H., Calestani C., QTL analysis to study the association between leaf size and abscisic acid accumulation in droughted rice leaves and comparisons across cereals, Plant Mol. Biol. 35 (1997) 155-165.

[32] Robison B.D., Wheeler P.A., Sundin K., Sikka P., Thorgaard G.H., Composite interval mapping reveals a major locus influencing embryonic development rate in rainbow trout (Oncorhynchus mykiss), J. Hered. 92 (2001) 16-22.

[33] Rodionov A.V., Chechik M.S., Lampbrush chromosomes in the Japanese quail Coturnix coturnix japonica: cytological maps of macro chromosomes and meiotic crossover frequency in females, Genetika 38 (2002) 1246-1251.

[34] Satterlee D.G., Johnson W.A., Selection of Japanese quail for contrasting blood corticosterone response to immobilization, Poult. Sci. 67 (1988) 25-32.

[35] Schmid M., Nanda I., Guttenbach M., Steinlein C., Hoehn M., Schartl M., Haaf T., Weigend S., Fries R., Buerstedde J.M., Wimmers K., Burt D.W., Smith J., 
A’Hara S., Law A., Griffin D.K., Bumstead N., Kaufman J., Thomson P.A., Burke T., Groenen M.A., Crooijmans R.P., Vignal A., Fillon V., Morisson M., Pitel F., Tixier-Boichard M., Ladjali-Mohammedi K., Hillel J., Maki-Tanila A., Cheng H.H., Delany M.E., Burnside J., Mizuno S., First report on chicken genes and chromosomes 2000, Cytogenet. Cell Genet. 90 (2000) 169-218.

[36] Shibata T., Abe T., Linkage between the loci for serum albumin and vitamin D binding protein (GC) in the Japanese quail, Anim. Genet. 27 (1996) 195-197.

[37] Shibusawa M., Minai S., Nishida-Umehara C., Suzuki T., Mano T., Yamada K., Namikawa T., Matsuda Y., A comparative cytogenetic study of chromosome homology between chicken and Japanese quail, Cytogenet. Cell Genet. 95 (2001) 103-109.

[38] Smith J., Bruley C.K., Paton I.R., Dunn I., Jones C.T., Windsor D., Morrice D.R., Law A.S., Masabanda J., Sazanov A., Waddington D., Fries R., Burt D.W., Differences in gene density on chicken macrochromosomes and microchromosomes, Anim. Genet. 31 (2000) 96-103.

[39] Solovei I., Ogawa A., Naito M., Mizuno S., Mac Gregor H., Specific chromomeres on the chicken $\mathrm{W}$ lampbrush chromosome contain specific repetitive DNA sequence families, Chromosome Res. 6 (1998) 323-327.

[40] Stock A.D., Bunch T.D., The evolutionary implications of chromosome banding pattern homologies in the bird order Galliformes, Cytogenet. Cell Genet. 34 (1982) 136-148.

[41] Tan Y.D., Wan C., Zhu Y., Lu C., Xiang Z., Deng H.W., An amplified fragment length polymorphism map of the silkworm, Genetics 157 (2001) 1277-1284.

[42] Van Haeringen W.A., Den Bieman M.G., Lankhorst A.E., Van Lith H.A., Van Zutphen L.F., Application of AFLP markers for QTL mapping in the rabbit, Genome 45 (2002) 914-921.

[43] Voorrips R.E., Jongerius M.C., Kanne H.J., Mapping of two genes for resistance to clubroot (Plasmodiophora brassicae) in a population of doubled haploid lines of Brassica oleracea by means of RFLP and AFLP markers, Theor. Appl. Genet. 94 (1997) 75-82.

[44] Voorrips R.E., MapChart version 2.0: Windows software for the graphical presentation of linkage maps and QTLs, Plant Research International, Wageningen, The Netherlands, 2001.

[45] Vos P., Hogers R., Bleeker M., Reijans M., Van de Lee T., Hornes M., Frijters A., Pot J., Peleman J., Kuiper M., Zabeau M., AFLP: a new technique for DNA fingerprinting, Nucleic Acids Res. 23 (1995) 4407-4414.

[46] Vuylsteke M., Mank R., Antonise R., Bastiaans E., Senior M.L., Stuber C.W., Melchinger A.E., Lübberstedt T., Xia X.C., Stan P., Zabeau M., Kuiper M., Two high-density $\mathrm{AFLP}^{(\mathrm{R})}$ linkage maps of Zea mays L.: analysis of distribution of AFLP markers, Theor. Appl. Genet. 99 (1999) 921-935.

[47] Waugh R., Bonar N., Baird E., Thomas B., Graner A., Hayes P., Powell W., Homology of AFLP products in three mapping populations of barley, Mol. Gen. Genet. 255 (1997) 311-321.

[48] Young W.P., Wheeler P.A., Coryell V.H., Keim P., Thorgaard G.H., A detailed linkage map of rainbow trout produced using doubled haploids, Genetics 148 (1998) 839-850. 